\title{
Paisagens urbanas: narrativas de Porto Alegre em perspectiva
}

\author{
Natalia Borges Polesso*
}

\begin{abstract}
Resumo
Neste artigo, apresentamos um panorama histórico e geográfico da cidade de Porto Alegre em 12 obras da literatura produzida por autores que nasceram, viveram ou vivem nesta mesma cidade. A partir desse panorama desenvolvemos um pensamento-paisagem (Collot, 2011) composto pelas narrativas, verificando os itens mais importantes da cidade que aparecem como um conjunto de referencialidade para sua construção. Nos amparamos nos estudos de Collot (2007 e 2011) e Westphal (2007) para paisagem e geografia; Sarlo (2005), Harvey (1999) e Jacobs (2001) para cidade; Franco (1992) e PESAVENTO (2002) para historia de Porto Alegre.

Palavras-chave: Paisagem. Urbanidade. Referencialidade. Romances. Porto Alegre.
\end{abstract}

\section{Urbanscapes: narratives of Porto Alegre in perspective}

\begin{abstract}
In this article, we present a historical and geographical panorama of Porto Alegre in 12 novels writen by authors who were born, lived or live in this same city. From this panorama, we develop a pensée-paysage (Collot, 2011), composed by the narratives, verifying the most important items of the city that appear as a set of referentiality for its construction. We are supported by the studies of Collot (2007 and 2011) and Westphal (2007) for landscape and geography; Sarlo (2005), Harvey (1999) and Jacobs (2001) for city; Franco (1992) and Pesavento (2002), for the history of Porto Alegre.
\end{abstract}

Keywords: Paysage. Urbanity. Referenciality. Novels. Porto Alegre.

Recebido: $30 / 03 / 2018$

Aceito: $27 / 11 / 2018$

* Universidade de Caxias do Sul (UCS), pós-doutoranda, bolsista PNPD/CAPES. 
A paisagem é um modo de observação humana que está intimamente ligado à experiência e, portanto, ao sujeito. Neste artigo, apresentamos e discutimos imagens de Porto Alegre presentes em 12 obras da literatura, produzidas entre 1897 e 2013. ${ }^{1}$ Os objetivos são: a) fazer um percurso panorâmico histórico e geográfico de como a referida cidade surge e se transforma na literatura no período mencionado, e b) destacar os elementos referenciais que a tornam essencial para as narrativas. Segundo Collot, a paisagem "não é pura representação, nem simples presença, mas o produto do encontro entre o mundo e um ponto de vista" (Collot, 2011, p. 18, tradução nossa). ${ }^{2}$ O ponto de vista narrativo nos interessa sobremaneira, pois é a partir dos narradores e das personagens que a cidade nos é contada, são eles que nos entregam os referentes e é a nossa leitura, como ato estético do pensamento, que a recria, daí a experiência um pensamento-paisagem ${ }^{3}$. Outro conceito que nos é bastante caro é o de referencialidade que, segundo Westphal (2007), tem o papel de não fazer do espaço um terreno móvel onde a ação ocorre, mas oferecer elementos que proponham diferentes possibilidades narrativas. O referente do discurso (a cidade), ou a referencialidade da obra (o conjunto de elementos narrativos da cidade), é composta por um repertório compartilhado e conhecido, formado por elementos da realidade, que nos coloca diante de um conjunto de itens e mentalidades. Chamamos esses itens construídos de realemas. $\mathrm{O}$ realema se torna um elemento muito significativo, porque ele está na cidade como item da paisagem, mas na literatura, encontra-se como constructo simbólico, intelectual, compondo as metáforas da cidade. Retomando o conceito de Westphal (2007), os realemas são realidades não linguísticas que formam um repertório de realidade (a referencialidade). Esse repertório não é ingênuo nem imune às relações físicas e simbólicas que mantém com a cidade.

Porto Alegre começou a ser povoada por imigrantes açorianos por volta de 1750. Em 1809, o pequeno aglomerado ganhou o status de vila e, $\log$ o mais em 1822, o de cidade. Conforme Sandra Jatahy Pesavento (2002), nas décadas seguintes, vias foram abertas, casarões e prédios públicos foram arquitetados, paços e praças foram inaugurados, igrejas e hospitais foram erguidos, um teatro foi construído e uma vida social e cultural se instaurou.

Segundo Polesso (2017), o romance Estrychnina, de 1897, dá início a Porto Alegre urbana literária, logo nas primeiras páginas do romance, encena-se A Dama das Camélias, de Dumas. Na plateia de um teatro, que segundo Luís Augusto Fischer, na apresentação da edição de 1998, tem como referente o Theatro São Pedro, os protagonistas, Neco Borba e Chiquita, se inserem nos costumes e nas práticas de qualquer cidade grande. Chiquita, moça do interior, despertava com a cidade, enquanto "A vida ruidosa e atraente da capital foi-lhe, no entanto, curando pouco a pouco a chaga que a nostalgia tinhalhe aberto no coração" (p. 57). A moça que habita a cidade nascente é a personagem que nos conecta com o estranhamento do lugar. Ela está na companhia de um flâneur, que conhece os modos de ser urbanos, e juntos vão desbravando cafés, praças, e a Rua da Praia, endereço preferido para passeios e observações dos costumes citadinos.

O coração de Porto Alegre parece sempre ter sido a Rua da Praia ou dos Andradas, a mais antiga da cidade. Essa rua sustenta grande parte do espírito do tempo da capital do Rio Grande do Sul, é nela que podemos observar suas mudanças nas narrativas. Um de seus elementos mais marcantes foi a chegada da luz elétrica em 1897. A luz elétrica, seca e áspera, na experiência dos narradores, iluminava de fato uma capital civilizada que rumava à completude de sua modernização. Ali, todos se encontravam num trânsito pleno de diversidade. O centro sempre manteve essa característica de integração.

1 Este artigo é fruto de minha tese de doutoramento Literatura e cidade: cartografias metafóricas e memória insolúvel de Porto Alegre (1897-2013).

2 No original : “[...] n'est ni une pure représentation ni une simple présence, mais le produit de la rencontre entre le monde et un point de vue." (COLLOT, 2011:18)

3 Conforme Collot (2011), quando um sujeito enquadra, por assim dizer, a paisagem, quando ele escolhe os elementos que a compõem e os relaciona no que se refere a questões físicas e simbólicas, ele imerge em um pensamento-paisagem. 
Conforme Sérgio da Costa Franco (1992), Porto Alegre já é uma cidade iluminada no final dos anos 1830, primeiro com lampiões e, mais tarde, com um sistema de distribuição de gás, após a instalação da companhia São Pedro Brazil Gaz Ltd, em 1874. Porém, só é em 1891 que a Cia. Fiat Lux se instala, trazendo a luz elétrica ao centro, ainda que de maneira precária. A confluência desses dois tipos de iluminação durou algum tempo, assinalando também a transição do velho para o novo, da vila para a capital. A luz elétrica é um índice de que havia uma atmosfera de progresso na cidade, como podemos observar no seguinte trecho de Estrychnina:

E as lâmpadas elétricas, como olhos esbugalhados de moribundos, iluminavam a rua a trechos, com a sua luz vivíssima e parada [...] Os empregados da iluminação pública principiavam a apagar os lampiões de gás. Começara a cair sobre a terra a aragem fria da madrugada. Uma claridade enevoada vinha se estendendo pelo céu, empalidecido e brumoso, e as torres da igreja, o alto dos grandes edifícios, a casaria toda da cidade iam a pouco e pouco surgindo fantasticamente da sombra. (AZURENHA et al., 1998, p. 96)

Transformar as lâmpadas elétricas em olhos esbugalhados é dizer que a observação do mundo e da vida mudara. A luz "vivíssima e parada" se contrapõe à luz instável dos lampiões, as lâmpadas não são mais apagadas por alguém, agora elas são os olhos autônomos da cidade.

No início do século XX, antes do que se considera ser de fato a instalação da modernidade, Andradina de Oliveira já descrevia Porto Alegre como uma cidade moderna, no livro O perdão, de 1910:

A rua extensíssima e movimentada, a Voluntários da Pátria, cingia uma parte da cidade com sua larga facha de progresso, entre murmúrios do rio azul e os rutilamentos do céo claro, como si agora é que fosse um caminho novo, com o apitar animados das suas machinas (sic), a série de obeliscos das altas chaminés, com os mil ruídos das engrenagens dos seus engenhos, com a vida immensa e movimentos das fábricas, e com a assombrosa vitalidade do seu commercio poderoso. E a agitação della era feita de tudo isso e mais as vozes dos que transitavam e o rumor dos bonds que se cruzavam, e o rodar atordoador dos carros e das carroças (OLIVEIRA, 1910, p. 219-220).

Notamos características de uma cidade já moderna e urbanizada, na acepção de Walter Benjamin. A rua movimentada aos olhos da narradora, o progresso, palavra-chave do Positivismo e do crescimento dos grandes centros urbanos, se contrapõe aos adjetivos "assombrosa" e "atordoador". Está exposta a tentativa de compreender o mundo e ao mesmo tempo temê-lo. Não é como Baudelaire descrevia a Paris nascente, mas algumas questões humanas reverberam na melancolia do assombro e do atordoamento para com a vida na grande cidade, que a narradora tenta humanizar para melhor compreender:

O mercado, o empório que o ventre insaciável da grande cidade não esvasia nunca, era rodeado de dezenas de carroças, atulhadas [...]. A Doca coalhava-se de barcos ennegrecidos, velhos, desbotados. Aqui o carvão enchendo uma porção delles [...]. Pelas ruas a vida da cidade se desenrolava na realidade das cousas (OLIVEIRA, 1910, p. 219-220).

O estranhamento da vida se desenrola no ventre da cidade, sem espaço, coalhado, pleno de eventos e itens que precisam ser identificados e compreendidos. Maria Lúcia Henriques (2010) afirma que no referido romance representa-se uma vida no estilo belle époque, o que, em certa medida, pode ser constatado, visto que os costumes, especialmente em cenas que acontecem no interior da residência dos Souza, são uma imitação de costumes europeus, os quais a elite cultivava. Contudo, as descrições da cidade não condizem com o referido estilo. A discussão de problemas urbanos começa a surgir desde então. O espaço do romance é o produto de uma tentativa de compreensão da experiência de urbanidade. $\mathrm{Na}$ fala de Armando, personagem forasteiro, revela-se a surpresa da grandeza de Porto Alegre: 
-E que surpresa quando cheguei. Porto Alegre é uma belíssima cidade! Um foco intellectual com todas estas escolas superiores e gymnasios equiparados. A indústria e o commercio me surprehenderam. Há extradordinária vida aqui, tio. O progresso desta terra é uma brilhante realidade. Os usos e costumes são os de centros adiantados. A cultura da mulher é já bastante apurada. As artes são aqui acolhidas com imenso carinho. Há gosto pela música e pela pintura. Cantam, bordam e vestem-se as mulheres. E são bonitas ás devéras, tio! (OLIVEIRA,1910, p. 73)

Oliveira evidencia que a mentalidade de Porto Alegre se intelectualiza com um aparato educacional completo (escolas superiores e ginásios), além da estrutura industrial e comercial que se desenha mais formalmente. De maneira perspicaz, ela expõe, na voz de Armando, a cultura da mulher sulina, questão muitíssimo cara à autora que militou em prol dos direitos da mulher, sua educação e autonomia.

Em 1935, completava-se o centenário da Revolução Farroupilha. Nesse ano, Erico Verissimo, com Caminhos cruzados, um marco na literatura urbana em Porto Alegre, ainda busca humanizar alguns referentes da cidade. A diferença é que nesse ano a cidade literária criada pelo autor se torna mais complexa com divisões, eixos e uma sociedade que começa a aparecer estratificada na literatura. No trecho que abre o romance, podemos observar alguns desses pontos:

Agora nas fachadas escuras começam a brotar olhos quadrados e luminosos. D. Vera acendeu o lampião e vai acordar o marido que tem que tomar o primeiro bonde. No mercadinho de frutas, Said Maluf abre a porta dos fundos para apanhar a garrafa de leite. Na casa do alfaiate espanhol chora o filho mais moço. Na meia-água vizinha, o Cap. Mota toma chimarrão na varanda, em mangas de camisa (está fazendo frio, mas não se deve quebrar um hábito de vinte anos). Fiorello já abriu a sapataria e, enquanto ferve a água para o café, o italiano bate sola, bate sola; na litogravura da folhinha, na parede, Mussolini em cima do seu cavalo, berra marcialmente: "Camicie nere!" Um trem apita. Um galo canta (VERISSIMO, 1976, p. 1)

As janelas da vizinhança são olhos a observar a cidade. O professor Clarimundo se distancia para compreender a configuração da vida. Os realemas que surgem vão desde um lampião, uma meiaágua, um mercadinho, a sapataria de um imigrante italiano, alguém que precisa tomar o bonde e, ao mesmo tempo o trem-máquina apita e o galo canta. O narrador e as personagens, a partir de diferentes lugares, oferecem visões múltiplas sobre a mesma cidade, os caminhos se cruzam.

A tentativa de dominar a cidade pela visão panorâmica aparece em diversos trechos do romance e pode ser fruto do início da verticalização e expansão do território da cidade. A personagem Salu vigia o movimento do centro em sua pequenez, que apenas pode ser constatada pelo distanciamento:

Salu debruça-se à janela. Lá embaixo na rua movimenta-se um exército de bichos minúsculos. Correm os bondes de capota parda; chatos e rastejantes, parecem escaravelhos. Uma confusão de cores e formas móveis, um entrebalançamento de fios de aço e de sons. Vermelhos pardos, os telhados se estendem ao sol. Coruscam vidraças. Flutua no ar uma névoa azulada [...] São como formigas - repetia ele. - Caminham, caminham e caminham. Sempre preocupados com o trabalho, os burros! Os formigueiros (e o velho fazia um gesto que abrangia a cidade) sobem para as nuvens... (VERISSIMO,1976, p. 17-18)

Quer-se dominar a paisagem. O distanciamento agora é possível pela configuração da cidade, por sua verticalização. Nota-se sua vastidão, que se constrói com a tríade da composição paisagística lugar-olhar-imagem, quando num gesto pode se tocar todos os elementos. Junto dessa vastidão está o desejo de abrangê-la e talvez de dominá-la:

Esta abertura é a condição da emergência da paisagem. Ela está ligada à conquista da posição ereta que define o homem como um "ser distante". Ela permitiu que nossos antepassados erguessem seu olhar, outrora, fixo ao chão e ao seu ambiente imediato, para o céu e para o distante, para desenhar um horizonte. É no cruzamento desses dois recursos, a verticalidade da figura humana e o horizonte que nasce a orientação do espaço, a partir desse momento, distribuída entre o céu e a terra, para cima e para baixo, com o dianteiro e o traseiro, a direita e a esquerda, o perto e o longe (COLLOT, 2011, p. 21, tradução nossa). ${ }^{4}$

4 No original: cette ouverture est la condition de l'émergence du paysage. Elle est liée à la conquête de la station verticale 
Desde a compreensão integral até o detalhe, o ser urbano se posiciona ao mesmo tempo como dominador e dominado, esmagado pela paisagem que ele nunca vai controlar verdadeiramente. Clarimundo tenta capturar sentido nessa imensidão:

Da sua janela, ponto culminante da Travessa das Acácias, o Prof. Clarimundo viaja o olhar pela paisagem. No pátio de D. Vera um cachorro magro fuça na lata do lixo. Mais no fundo, um pomar com bergamoteiras e laranjeiras pontilhadas de frutos dum amarelo de gemada. Quintais e telhados, fachadas cinzentas com a boca aberta das janelas. [...] Vem e outras ruas a trovoada dos bondes atenuada pela distância. Grasnar de buzinas. Num trecho do Guaíba que se avista longe, entre duas paredes caídas, passa um veleiro.

Clarimundo debruça-se à janela... Então tudo isto já existia antes, enquanto ele passava as horas às voltas com números e teorias e cogitações, tudo isto tinha realidade? (VERISSIMO, 1976, p. 39)

A janela é uma boca aberta que enquadra a multiplicidades. A rua se torna "um mar encapelado de cabeças multicores" (p. 63) e de repente "o sol já se escondeu por trás dos edifícios mais altos" (p. 63). A cidade aponta para cima e permite que apenas alguns tenham a experiência de abrangê-la. Há diversas menções ao edifício Colombo, capaz de ser visto e de servir de base para a vista. E é ainda pela janela que Clarimundo avalia o progresso:

O progresso mecânico é horrível, pois significa bondes, automóveis, gramofones, rádios, máquinas e mais máquinas! A admiração de Clarimundo pela ciência que tornou possível todas essas engenhocas fica limitada aos domínios da teoria. (VERISSIMO, 1976, p.156)

O fascínio: comparar a janela com um microscópio, de onde poderia analisar os pequenos e grandes detalhes da vida urbana, é a configuração clara de um ponto de vista, de onde se destaca uma paisagem. O progresso está ligado às máquinas, à mecânica, ao passo que a ciência o ajuda a compreender a necessidade desses fatores, porém a teoria não lhe assegura o gosto pelos inventos e nem sua operacionalidade. Uma paisagem afetada pela maquinaria da modernidade se cria, o que atrai e desagrada a personagem. Eis a contradição da paisagem urbana, que reside na experiência de cada sujeito.

É por meio da família Pedrosa, do interior do Estado, que um narrador expõe suas expectativas de compreensão da "metrópole". Sabemos que Chinita quer ser artista de cinema e Manuel quer conhecer a capital. "Para ela, Porto Alegre significava uma vida nova: sociedade fina, automóveis, passeios, cinemas, bailes, ruas muito movimentadas, luxo e gozo. Manuel sonhava com farras homéricas" (VERISSIMO, 1976, p. 29). A experiência da urbanidade se apresenta pelo desejo. O automóvel parece ser uma espécie de símbolo do consumo e da independência; o passeio, os cinemas e os bailes, a culminância do envolvimento social, o contato com o mundo dentro da cidade e seu alcance mundial através dos filmes. Os bailes seriam a maneira de Chinita ser a estrela que sonhava. Manuel resume todos os índices em grandes farras. A variedade e a quantidade de personagens possibilita que o narrador jogue com os pontos de vista, trazendo diferentes ângulos da paisagem para a construção da ideia de urbanidade da obra.

Em E as águas invadiram a metrópole (194?), a chegada de Aldo e Doris, no vapor da companhia Arnt, também carrega a ideia de experiência na metrópole. Nesse romance, há um distanciamento, pela margem do rio, que nos apresenta ícones referenciais já mencionados agora mais carregados de importância, simbolizando o progresso:

Milhares de pontinhos luminosos estendiam-se desde a ponta da cadeia até o bairro dos Navegantes. A enorme chaminé da usina elétrica fumegava. Os arranha-céus altivos e eretos cada qual querendo subir mais numa ânsia louca de aguilhar o azul do céu. (MARRONI, [1942?], p. 78)

qui définit l'homme comme un "être des lointains". Elle a permis à nos ancêtres de porter leur regard, autrefois rivé au sol et à leur environnement immédiat, en direction du ciel et jusqu'aux lointains, pour y tracer un horizon. C'est au croisement de ces deux traits, la verticale de la silhouette humaine et la ligne d'horizon, que naît l'orientation de l'espace, désormais distribué entre le ciel et la terre, le haut et le bas, l'avant et l'arrière, la droite et la gauche, le proche et le lointain. 
A luz continua sendo assunto importante, mas, além disso, a importância do rio Jacuí e do Guaíba para a mobilidade na capital é fundamental. Muito do que chegava ou saía tinha seu trajeto determinado pelo rio. Inclusive o trânsito das pessoas que chegavam ou partiam. A metáfora da água, sua fluidez e seu arrebatamento são constantes na narrativa. O narrador observa a cidade desde o Guaíba, um elemento primordial nas narrativas da cidade de Porto Alegre e, nesta obra, o lugar por onde se chega e por onde se pode tomar consciência da grandeza da fragilidade da cidade. É a água das chuvas e da enchente que quase separa o casal protagonista, "Então é esta maldita enchente que impede o meu esposo de estar ao meu lado...” (MARRONI, [1942?], p. 197). No fim do livro, temos uma Porto Alegre abandonada, o casal volta para Esperança (Guaporé) com o filho, deixando a capital de barco. Na década de 1940, Porto Alegre possuía 385 mil habitantes. As pessoas disputavam as ruas do centro com carros e bondes, e alguns bairros ao redor despontavam em crescimento. Obras de implantação de infraestrutura eram realizadas e o progresso tinha um sentido visível e palpável no corpo da cidade. O crescimento de novas indústrias e do sistema portuário foram elementos relevantes para a dinâmica de Porto Alegre; o prolongamento de avenidas importantes como a João Pessoa e a Borges de Medeiros foi feito nessa década; bem como alguns aterramentos na área do porto. A área da saúde também se beneficiou com o crescimento do sistema de distribuição de energia elétrica. Uma história de Porto Alegre, estudo coordenado por Walter Spalding e apoiado pelo Instituto Histórico Geográfico do Rio Grande do Sul, foi publicada. Enquanto o crescimento econômico se evidenciava, a consequência foi uma dilatação da periferia. Monteiro (2006) entende que

Os espaços urbanos sofreram, na década de 1940, grandes transformações, provocando uma experiência de ruptura com o passado herdado e de perda de referenciais para a manutenção da memória das experiências urbanas da sociedade [...] as reformas e as consequentes mudanças na estrutura urbana não ocorreram sem causar tensões na sociedade porto-alegrense. A demolição de muitas quadras, prédios e casas causaram a expulsão de populações e a transformação de espaços centrais da cidade. (MONTEIRO, 2006, p. 58)

Partindo das águas do Guaíba, em Estrada nova (1954), a experiência de urbanidade indica e debate o processo de modernização e as consequências do modelo capitalista inerente a essa cidade.

Uma beleza o entrar do sol sobre o Guaíba e as Ilhas. E, no lado direito da Voluntários, as primeiras luzes das lojas davam-lhe uma impressão de vida e movimento de que não tinha lembrança. Nunca lhe ocorrera a ideia de andar por ali àquela hora. Ignorava que aquela zona fosse assim, meio misteriosa, pelo menos pra ele, diferente do resto da cidade, principalmente no anoitecer. Com efeito, a Voluntários da Pátria, próxima ao cais, com trilhos de bonde e linhas de trem, com seus inúmeros hoteizinhos, pensões, bares, armazéns, enormes depósitos de atacado, operários largando o serviço, prostitutas e indivíduos suspeitos parados nas esquinas - batedores de carteira e passadores do conto do vigário, à espreita dos interioranos que se hospedavam nas imediações da estação, todo esse conjunto, no qual contrastavam, entreverados, vagabundos e trabalhadores, honestos e salafrários, imprimia àquela rua um interesse bem mais raro e atraente do que o retirado e pacato bairro do Partenon, onde, de estranho, só havia o Hospício, e isso mesmo metido lá para dentro, fechado à curiosidade pública. (MARTINS, 1985, p. 23)

A cidade agora comporta zonas misteriosas e a diversidade se segmenta. É possível fazer comparações de localidades que não mais se contrapõem, mas se parecem. A narrativa evidencia a situação marginal oriunda do crescimento das cidades. Especialmente das famílias pequenas que tinham sua economia baseada na agricultura e que foram forçados a deixar suas terras pela criação de grandes latifúndios. Entre as décadas de 1930 e 1950, o Estado sofreu amplas modificações em sua estrutura física e econômica, a cidade, como formação, acabou sendo o destino dessas famílias que, sem condições de habitá-la, começam a se estabelecer em suas margens:

$\mathrm{O}$ trem deixava a cidade para trás. Apareceram as primeiras malocas acompanhando a estrada. Um avião sobrevoava serenamente o campo de São João. Rasgou-se a vista a várzea do Gravataí, de um verde uniforme, úmido e lustroso ao lusco-fusco da noitinha. (MARTINS, 1954, p. 23) 
O afastamento também se amplia na visão panorâmica desde um avião, avista-se as malocas de beira de estrada e também os espaços ainda não ocupados, as várzeas e os campos, ressaltando que não é a falta de espaço que exclui as pessoas, mas a falta de meios para ocupá-lo. No pensamento de David Harvey (1999), o direito à cidade não é simples questão de liberdade, mas de acesso e recursos. Uma cidade está intrinsecamente conectada com os processos coletivos de ocupação e dominação que são políticos e econômicos.

As personagens tinham esperança de encontrar naquele espaço, novos rumos para suas vidas, novas formas de ser e pensar. No entanto, o que se encontra no romance são essas distâncias de pensamentos, de compreensão da vida e das distâncias físicas: do campo e da cidade, da Estância Velha e da Capital, da ditadura e do comunismo, do moderno e do antigo. Longe de ser um livro maniqueísta, Cyro Martins traça as distâncias entre pontos dicotômicos com diálogos bem representativos do pensamento da época. É por meio deles que o autor expressa o seu entendimento de mundo e seu descrédito na ideia romântica de cidade. O êxodo retratado neste livro vai apenas engrossar o caldo da miséria, problema que surge em outros romances, já bastante enraizada na estrutura física e social da cidade. Por este viés, percebemos que a política é um assunto bastante tratado, parte importante nesta literatura que forma a cidade. A Porto Alegre dos romances parece ser habitada sempre por cidadãos politizados. Uma ou outra personagem sempre tem uma opinião ou ligação política. Ainda em Estrada nova, a questão política é essencial para retratar a Porto Alegre após a Segunda Guerra:

Por isso, quando ligou o rádio, já o locutor informava aos "céus da América", esbaforidamente, a ação da polícia em Porto Alegre que, segundo dizia, havia descoberto e anulado um plano subversivo de proporções, organizado pelos comunistas. Cerca de cinqüenta implicados tinham sido presos. A cidade estava em pé de guerra, com os edifícios das repartições públicas, a usina de energia elétrica, a estação de bondes, a estação ferroviária e outros locais, devidamente guarnecidos por tropas da Brigada Militar. (MARTINS, 1985, p. 45)

A ideia de comunismo ameaça a configuração da cidade. A forma mais simplificada de reagir a esta ameaça, de acordo com o narrador, é a organização militar, que no trecho acima aparece ocupando diversos pontos da cidade. Interessante que a polícia já aparece não como modo de proteção dos cidadãos, mas de coação. O rádio surge como elemento conector entre a cidade e a campanha e entre os interesses do povo e os do governo, evidenciando conluios com grandes corporações:

[...] naqueles tempos incertos, com a Guerra recém terminada, o Estado Novo caído, o comunismo mandando na metade do mundo. E os jornais e os rádios não cessavam de falar em reformas sociais, em direitos dos trabalhadores, em greves, em Reforma Agrária, em assistência social, em salário mínimo e outras complicações pelo estilo. Isto, sem contar com a possibilidade de quebra de bancos. (MARTINS, 1985, p. 60)

A fragilidade dos direitos do cidadão é exposta na voz do narrador, numa perspectiva protecionista do Estado, enquanto as pessoas ouvem o rádio, uma aura de medo se instala com a possível quebra dos bancos. Assim fica evidente o ponto de vista político crítico, escolhido para a observação da cidade.

O ambiente de instabilidade continua na década de 1960 em Mário-Vera Brasil, 1962/1964 (1983), de Tânia Faillace. A autora escolhe um ponto de vista político, porém o faz com uma narrativa da intimidade, pois a protagonista, Vera, vai "mapeando aquela cidade no rastro de Mário" (p.24), o homem pelo qual se apaixona enquanto perambula pelo centro, depois de um dia de trabalho. Uma Porto Alegre pré-golpe militar aparece com as tensões políticas. Vera tem a cidade como símbolo e concretização de sua liberdade, que, ao final do romance, é subtraída pessoal e politicamente. A cidade para ela, moça independente nos anos 1960, equivale a uma aventura proibida e solitária. “Acabava sempre indo para a rua. Como um homem" (p.20), para a protagonista não era um problema que a julgassem, queria o direito de "caminhar pela rua, entrar sozinha em lancheria, ir ao cinema 
sozinha, sentar em praça sozinha... não convidar ninguém para ir à sua casa esquisita...” (p.32). O romance contém diversas cenas que se passam à noite, nas ruas e praças da cidade, o que colabora para o ambiente de interdição e perigo, ponto de vista que a protagonista pretende construir.

Na década de 1960, muitas praças foram construídas ou reformadas em Porto Alegre, por isso talvez a praça corresponda a um lugar de extrema importância no romance. Na praça, Vera se encontra com Mário. Para a praça, ela foge ao não querer ir à casa da tia, com quem mora. As personagens passam por diversas praças durante seus passeios. É na praça que ocorrem as manifestações de grupos sociais. São as novidades da estrutura citadina da época, reverberando no olhar da protagonista exposto no romance. A cidade crescia enormemente, em estrutura, mas também em problemas sociais, vista a situação política e as manifestações ocorridas na época, por exemplo, a de 2500 mineiros, requerendo seus direitos, no Largo da Prefeitura, episódio que é relatado no romance. A cidade de Tania Faillace está sempre povoada por uma multidão anônima. Como jornalista engajada em questões políticas, a autora insere em seus livros muitos episódios verídicos, notícias de jornais em grandes sumários da situação mundial, aos quais Mário e Vera se somam.

Apesar da crescente circulação de automóveis, ônibus e táxis, no início dos anos 1960, a utilização do bonde ainda prevalece no romance de Faillace, sendo um elemento fundamental para a ligação do centro com o Quarto Distrito, zona industrial. Os bondes cumpriram a função de elemento conector entre os mundos de Mário e Vera. Contudo, foi nesta década que o bonde foi desativado e o transporte privado automobilístico passou a ser mais incentivado. A mobilidade mudou de uma década para outra e isso pode ser notado nos percursos dos protagonistas e demais personagens dos romances. Com o passar dos anos, a linha do bonde deixa de ser o trajeto de maior concentração, bem como o centro, seu destino final.

Se Mário-Vera Brasil, 1962/1964 (1983) é um romance que tem muitas cenas noturnas, Os voluntários (1979) faz-se quase completamente noturno. O referido romance cobre desde 1935, quando os pais de Paulo, o protagonista, se estabelecem na rua Voluntários da Pátria, até 1970, na noite em que Paulo, Capitão e Elvira tentam zarpar com um rebocador do cais do porto para Jerusalém. A Porto Alegre dos imigrantes notívagos vai se mostrando numa narrativa que mistura a trajetória pessoal de Paulo e os desejos das pessoas que ele encontra. Podemos ver essa Porto Alegre noturna e esses trajetos que se cruzam em uma geografia que o autor adjetiva como sensual:

A esta hora os operários, os caixeiros, os funcionários já tinham ido pra casa. De seus quartos nos velhos sobrados as mulheres começavam a emergir. Caminhavam lentamente, equilibrando-se nos altos saltos; ou então postavam-se nas esquinas, encostadas à parede. Ou ficavam sentadas no interior de bares sombrios, os olhos reluzindo na semi-obscuridade. Aquilo regurgitava de mulheres. Um rápido exame da geografia sensual de Porto Alegre mostraria uma cidade ocupada por esse amável exército. Na Pantaleão Telles, junto à ponte de pedra em que os Farrapos travavam furiosas batalhas, um numeroso contingente entrincheirado nas casinhas da Cidade Baixa, na Azenha, Cabo Rocha era um importante reduto. No Cristal, Monica reinava solitária e esplêndida, com seu luxo, seu Quarto de Espelhos. Mas havia ainda lugares mais fantásticos. O cabaré das Normalistas, onde, segundo a lenda porto-alegrense, as moças deixavam cair as máscaras da inocência, ao invés de olhares ingênuos, um pouco sonso, piscar malicioso de olhos muito pintados; ao invés de saia azul e da blusa branca, vestidos colantes, de decotes ousados; ao invés de hinos escolares, cançonetas pícaras. E tudo de graça, o prazer pelo prazer. (SCLIAR, 1979, p. 41-42)

Esses locais servem ao arquétipo de uma cidade obscura. Esse mundo noturno, um pouco o mundo da interdição de Vera, no romance de Faillace, se constrói agora percorrido por um olhar masculino. O mundo da obscuridade também aparece na questão da imigração. Paulo, cujos pais haviam se estabelecido em Porto Alegre na década de 1930, considerava-se porto-alegrense e seu ponto de vista nos convida a experimentar a estranheza das pessoas:

Que gente estranha, aquele Benjamim, aquele Samir. Gente estranha, vinda de terras estranhas. Uma coisa contagiosa: aos poucos tudo, ali no bar, as pessoas, os objetos, começavam a adquirir um ar 
estranho. Me deu raiva, uma súbita vontade de gritar, zarpem já daqui, seus energúmenos, infiéis, vão para a terra de vocês, me deixem em paz, eu pertenço a Porto Alegre, ao bonde Navegantes e a igreja do Rosário, ao Caminho Novo, à praça Parobé, aos plátanos da Redenção, ao banco da Província, à Santa Casa, às ilhas do Guaíba, à grutinha da Glória, ao Alto da Bronze. (SCLIAR, 1979, p. 144)

O desejo de ir embora começa a fazer parte da ideia de cidade. Se, antes, Porto Alegre era destino, agora é ponto de partida. Em O perdão e Caminhos cruzados, o desejo de ir embora aparece, no primeiro, como fuga frustrada e, no segundo, como passeio a uma grande capital do País. Contudo, não é a insatisfação com a cidade em si que gera a frustração. A incompletude de estar em Porto Alegre, do que ela não oferece, começa a se fazer mais forte nessa época, quando seus habitantes já passam a achar que a grande metrópole sulina é tão provinciana quanto qualquer cidade do interior:

O que me levava a querer viajar? Generosidade, ou saco cheio? Passava eu então por uma fase difícil de minha vida. No bar olhava os pastéis e me perguntava: é isso então? Será isso daqui por diante, até a hora da morte? O bar, e a Voluntários, e Porto Alegre? Amigos meus a esta altura já estavam há tempos no centro do país, ou mesmo no exterior, uns administrando empresas, outros com bolsas de estudo ou no serviço público. Aninha tornara-se modelo, às vezes eu a via na TV. E eu? Ficaria em Porto Alegre? (SCLIAR, 1979:174)

A vida na capital não poderia ser menos excitante, como enfatiza o narrador. O centro do País e o exterior são opções melhores. Ficar em Porto Alegre é ficar para trás. A cidade não é mais tão atraente.

Contudo, na década de 1980, em Rastros do verão (1986), de João Gilberto Noll, a ideia de retorno aparece. $\mathrm{O}$ ambiente desértico e denso do narrador cria uma Porto Alegre fechada em si mesma, a ser explorada, revisitada, quase com exotismo. A rua e a errância são cruciais na narrativa, pois o objetivo é exatamente não chegar a lugar algum ou não chegar ao lugar preciso, como se a cidade fosse mesmo um deserto em que o protagonista se perde e descobre miragens. Há um prazer na descrição dos lugares, um amor irrestrito, embora difícil, pelas ruas e locais estranhos. No romance de Noll, a solidão se transmuta na paisagem urbana e no interior da personagem, o que se demonstra através das poucas falas, dos longos silêncios e dos espelhamentos contemplativos entre personagem e cidade.

O protagonista chega à rodoviária numa terça de carnaval, quando as ruas estão vazias. Ele caminha até a Praça Quinze de Novembro, passando pela passarela e observando a cidade, do alto, a torre da Igreja das Dores, para o alto, o cinema, o Mercado, até chegar à Avenida Júlio de Castilhos. Lá ele encontra um garoto e inicia uma conversar. O garoto conta que o pai o abandonou e sua única notícia foi uma carta enviada do Rio de Janeiro. Mais tarde, revela-se o motivo da volta do narrador: visitar o pai enfermo. Garoto e homem criam uma conexão e vão os dois, com suas solidões amparadas, traçando uma Porto Alegre que transita entre um rastro de realidade e outro de sonho. O ponto em que o retorno se evidencia dá-se logo no início do romance, quando o narrador reconhece uma avenida e a sua imutabilidade:

Peguei uma avenida que levava ao centro. Li a placa de ferro pregada na parede: Avenida Júlio de Castilhos. Essa avenida está igual, pensei. Havia um profundo silêncio. Eu não via pedestres nem carros. Aproveitei a primeira rua lateral para mijar. Numa ponta da rua via-se o porto, na outra, casas de pequeno comércio, todas fechadas, com exceção de uma com seus vestidos de verão esvoaçando brandamente pendurados na marquise. Senti uma brisa, espichei um pouco a mijada. Só no ponto onde eu estava ficou sombrio. Olhei para o céu e vi que sobre mim pairava uma nuvem espessa. $\mathrm{O}$ resto em volta, azul. (NOLL, 1986, p.10)

A cidade é estranha, mas tão sua, que a personagem pode mijar nela sem maiores preocupações e ainda olhar o céu, que, num presságio, envia uma nuvem para assombrá-lo. Mas o que ocorre é sempre algo onírico, por vezes, obscuro, como o episódio de um prédio abandonado nas proximidades da Auxiliadora: 
O táxi passava pelo bairro da Auxiliadora. Entrou à direita numa rua chamada Maryland. Parou na frente de um pequeno edifício todo escurecido pelo tempo. Notei que havia uma rachadura entre o térreo e o primeiro andar. Dei o dinheiro ao motorista. Disse que não precisava troco [...].

Subindo as escadas do prédio o garoto me falou que eu estava indo na casa de um amigo que tinha uma enorme tatuagem de uma âncora no braço, talvez de uma caravela. (NOLL, 1986:77-78)

A rua oferece apenas a sede, o calor e o deserto, que embaralha pensamento e sonho, os interiores dos apartamentos, quebram o silêncio, com poucas palavras e com a interação de corpos sempre exaustos.

Essa narrativa mais interior continua em Duas iguais (1998), de Cíntia Moscovich. A primeira parte está situada durante ditadura, no bairro de origem judaica, o Bom Fim. A protagonista Clara se apaixona por sua melhor amiga, Ana. Ambas se envolvem em protestos políticos, quando do desaparecimento de um professor. O contexto obriga Clara a se autoexilar em Paris. Na segunda parte, quando da volta de Clara, podemos observar um percurso que se repete quase obsessivamente: o de Clara até a casa de Ana, sendo o principal realema a rua Auxiliadora. Clara põe Ana como um ponto de desejo no meio da cidade e é em sua órbita que a protagonista se desloca. A morte de Ana desencadeia uma narrativa da memória dessa cidade, desse trajeto e da relação de Ana e Clara, expondo uma Porto Alegre de impressões. Uma cidade impossível, que existe apenas na memória. O que mais pesa nas descrições sucintas é o distanciamento físico e psicológico da personagem para com a cidade. Ela é, assim como o personagem de Noll, uma estrangeira. A narrativa de Moscovich cria uma Porto Alegre pautada nas impossibilidades e os poucos lugares mapeados acabam tendo grandes separações entre eles, no plano geográfico e histórico, como se o afastamento pudesse gerar uma cidade-lacuna.

É em dois tempos também que Daniel Galera em Mãos de cavalo (2006), divide Porto Alegre em terrenos irregulares. Com seu protagonista, Hermano, durante sua adolescência, percorremos a cidade de bicicleta, especialmente a zona sul, suas ruas, sua memória idílica, uma cidade emocional e ao mesmo tempo dolorida. Em capítulos intercalados, seguimos com Hermano, adulto, numa Porto Alegre de ruas largas e trajetos lineares. Dois opostos: na adolescência a distância e os labirintos da memória; na vida adulta amplas avenidas em percursos motorizados e quase impessoais.

[...] apreciar rapidamente a vista até que o olhar trave na água do Guaíba lá longe, salpicada do branco das velas dos veleiros. À sua direita, agora, os quarteirões são ocupados por casas construídas há não mais que um ano, várias delas com a pintura e as telhas ainda imaculadas, separadas entre si por miniaturas de matas fechadas. À sua esquerda predomina um terreno árido coberto por longas faixas de areia dura, alaranjada e erodida que se estendem em declive até a base do morro e dão lugar a uma zona plana onde ruas rigorosamente retas delimitam quarteirões retangulares subdivididos em lotes à venda. O loteamento da zona sul de Porto Alegre é novo e pouca gente, até o momento, se motivou a estabelecer moradia por ali. O ciclista (urbano) é um pioneiro decidido a mapear com suas rodas destemidas cada metro desta zona inóspita. (GALERA, 2006, p. 12)

Esse é o primeiro percurso. Um narrador em terceira pessoa é estabelecido, ele observa meticulosamente o caminho do ciclista urbano, mais tarde revelará o caminho de Hermano adulto. No momento em que o ciclista a inspeciona, a cidade é vazia, quieta, composta pela curiosidade de um garoto. A frase de abertura do livro indica: "não há terreno impossível para o Ciclista Urbano" (GALERA, 2006, p. 9). A narrativa é um percurso entremeado de memórias. Isso fica claro no trecho em que, lembrando do nome da filha, Hermano sai de seu trajeto habitual para mergulhar num trajeto íntimo de seu passado:

O nome suscita uma nostalgia difusa, não de todo agradável, pra dentro da qual tem a sensação de penetrar fisicamente ao deixar o último trecho reformado da Aparício Borges e prosseguir caminho naturalmente pela avenida Teresópolis, que segue em obras por algumas centenas de metros até dar lugar a um cenário que lhe parece preservado, com o mesmo asfalto antiquado e os canteiros centrais com árvores enormes que lembrava ver com frequência até uns cinco anos atrás, quando ainda 
morava na zona sul e costumava passar por ali. Fantasia que a continuação interminável da Terceira Perimetral é uma ameaça que o persegue e contra a qual agora, dentro do carro, está apostando uma corrida, como já tinha apostado corrida contra a sombra de nuvens em estradas. (GALERA, 2006, p. 96-97)

Um item do presente desencadeia um percurso que não é apenas geográfico, mas temporal e pessoal. Doreen Massey (2008) afirma que a vida é tanto espacial quanto temporal e não há meios para estabelecer uma fronteira entre essas noções nem hierarquizá-las. A equação tempo-espaço resulta das experiências humanas, no caso, de memória e percurso. $\mathrm{O}$ espaço é reconhecido, porque já percorrido, logo relacional, construído. Depois é percebido como múltiplo, porque se sobrepõe ao tempo; e, por último, plástico, porque passível de ressignificações:

o concreto das novas avenidas avançava como uma onda gigante e vinha cobrindo o asfalto, as calçadas, as árvores, os pontos de ônibus e os veículos atrás dele, e era necessário afundar o pedal do acelerador e chegar à Esplanada, antes que fosse tarde. Se o cimento o alcançasse, seria ele também transformado em cimento, e dessa vez não ia adiantar a Nara gritar e fazer cócegas, permaneceria para sempre aprisionado na paisagem monocromática, [...]E assim, rapidamente, a avenida Teresópolis se transforma na avenida Nonoai que se transforma na avenida Eduardo Prado, um trajeto ainda adormecido em que o progresso urbano dos últimos cinco anos deixou marcas variadas porém relativamente superficiais. Motéis decadentes, trailers anunciando promoção de xisbacon e alguns terrenos desocupados deram lugar a mini mercados, condomínios residenciais de baixa renda e templos as Assembleia de Deus com enormes placas na fachada exclamando "Pare de sofrer!'”...]. (GALERA, 2006, p. 96-97)

O caminho até a zona sul é um retorno ao refúgio da infância, que leva Hermano adulto a uma corrida simbólica contra o concreto que embrutece a cidade e que o embruteceria. Hermano se transformaria em vítima, paralisado numa paisagem monocromática entre o passado e o presente. $\mathrm{O}$ retorno à zona sul e o reconhecimento da área ou, na verdade, o desconhecimento da área, também é o retorno a si e seu próprio desconhecimento. A paisagem é parte do sujeito, ele se vê na paisagem.

Dos percursos de si que se desdobram no tempo, mais evidentes a partir da década de 1990 na literatura, chegamos a Habitante irreal (2011), de Paulo Scott. Por vezes, erros dão origem a fraturas irreparáveis e é isso que motiva Habitante irreal. Jane Jacobs (2001) alerta que "Para que maravilhas sejam executadas, as pessoas estigmatizadas pelos planejadores são intimidadas, expropriadas e desenraizadas" (p.3). A autora afirma que as cidades são um imenso experimento de tentativa e erro. A fratura da cidade no romance tem início em 1989, quando o protagonista Paulo, encontra a adolescente indígena Maína, na beira de uma estrada. Logo, ele se dá conta de que seus mundos não podem se integrar. Não é apenas o Guaíba ou a ponte que os separa, a distância é outra, é cultural e social. A vida da indígena está localizada pontualmente em poucos lugares no romance, Barrado do Ribeiro, é um deles. A comunidade indígena não tem direito à cidade, não pode pertencer e ainda está ameaçada de perder os lugares que restaram para sua moradia e sustento, como podemos perceber no seguinte trecho :

A kombi sai do Morro Santana (um dos que formam a chamada Crista de Porto Alegre, a cadeia de morros formados, pelo Morro Santana, Morro da Companhia, Morro da Polícia, Morro Pelado, Morro, da Pedra Redonda, Morro Teresópolis e Morro do Osso), de onde os caingangues retiram Cipó-Guaimbê pra fazer seu artesanato, área que vem sendo ameaçada pela especulação imobiliária crescente. (SCOTT, 2011, p. 129-130)

A equipe de estudiosos formada pelas personagens Henrique e Luisa expõe o exotismo do indígena dentro da cidade. O narrador informa a relação dos morros com os indígenas e a relação da urbanização, associada à especulação imobiliária, com os morros.

O envolvimento afetivo entre Paulo e Maína leva o rapaz a tentar aproximar e modificar seus mundos. Paulo tenta construir uma casa no acampamento indígena, para que Maína, sua mãe e irmãs 
possam "viver melhor". A ideia não se concretiza. Paulo acaba se desentendendo com um policial e é mandado pelo pai a Londres, para evitar maiores confusões. Enquanto Paulo está em Londres, finalmente seu mundo e o de Maína se fundem: ela está grávida. O filho, Donato, é o protagonista da segunda parte do livro, quem empreende um movimento de retorno às origens, retorno à fratura inicial, não para tentar repará-la, mas para fazê-la visível, jamais esquecida.

É também num encontro inusitado, no percurso de Catarina, jovem de classe alta, que a fratura se torna novamente visível na narrativa:

Caminham até a entrada do Café do Porto e se despedem [Catarina e o jornalista]. Ela sai distraída pela Padre Chagas (está no bairro onde nasceu, onde as coisas funcionam, onde pode passear a esmo), então vira à esquerda na Fernando Gomes e vai até a Vinte e Quatro de Outubro. Deveria seguir alguns metros pela calçada da frente do jardim-praça do DMAE e depois pegar a Miguel Tostes e, na sequência, a Vasco da Gama até chegar à livraria quase na esquina da Fernandes Vieira e conferir se o álbum sobre dança popular na década de vinte veio da distribuidora. Mas uma figura incomum, essa figura parada em frente ao portão do jardim do DMAE, chama sua atenção. Não é parecido com nada do que ela já tenha visto. É alguém usando uma espécie de máscara-armadura de madeira que desce até a pelve e lhe cobre tórax, pescoço, rosto. Uma peça única presa aos ombros e à nuca por cintas de couro cru e fivelas dourado claro opacas, no mesmo tom da madeira. (SCOTT, 2011, p. 208)

Donato ocupa a cidade com uma imagem ligada a sua ancestralidade, mas naquele espaço está completamente deslocado, um elemento indecifrável na paisagem. Ele corporifica a própria fratura dos mundos. As relações de poder determinam a Porto Alegre nesse romance. A cidade se faz um laboratório de tentativa e erro que vai se construindo sobre a premissa do desenraizamento das populações e o exercício dos poderes de dominação.

Quando a fratura não basta, erguem-se muros. Um dia todo mundo vai dar de cara com uma parede. Essa é a premissa de O beijo na parede (2013), de Jeferson Tenório, que narra uma Porto Alegre crua na voz de João, menino de 11 anos. Ele nos mostra como se vive à margem do que é direito. A narrativa começa com dois acidentes: o do Ayrton Senna e o da avó de João, na Avenida Protásio Alves. A conclusão informa que todos vão bater de frente em alguma coisa, morrer e ir para um buraco, não importa se campeões do mundo ou se pessoas comuns. Depois, João nos conta sobre o Rio de Janeiro, onde morava, a morte de sua mãe e uma sucessão de perdas, que o leva a morar em uma cidade triste, estranha e sem mar:

Gastamos um dia inteiro para chegar a Porto Alegre. Nunca tinha visto tanto morro, pasto e vaca durante a viagem. Antes de chegar, a única coisa que eu sabia é que era um lugar frio, pois meu pai vivia me contando sobre a sua infância na Cidade Baixa, que eles não tinham isso, não tinham aquilo [...]. Mas vou dizer a vocês que Porto Alegre não é só uma cidade fria. É também uma cidade triste. [...]. Não sei dizer o motivo da tristeza dessa cidade, mas acho que as coisas não precisam de motivos para serem tristes. [...] Meus tios moravam em Viamão. E eram todos brancos. (TENÓRIO, 2013, p. 17)

No decorrer do romance, entendemos como essa tristeza se avoluma ao seu redor, vai tomando a cidade inteira, expondo toda sua sujeira material e humana. A felicidade é um luxo que poucos podem comprar. A frieza do lugar não é meramente física, é uma crueza de tratamento, oferecidos pela estrutura das grandes cidades. As relações de afeto parecem acontecer mais pela necessidade do convívio do que pela escolha amorosa. Da estranheza, a personagem nota a cor das pessoas que vivem ao seu redor e logo adiante se identifica como filho de um pai branco com uma mãe negra, "Por isso tenho essa cor meio cinza e meio marrom, entenderam? Na família do meu pai, como eu disse, eram todos brancos, e depois eu soube que eles não queriam ter um parente pretinho como eu por perto" (Tenório, 2013, p.18)

A narrativa, em maior parte, se desenvolve nas proximidades do Guaíba e da a Avenida Farrapos, situada nesse quadrante está a casa de João com o pai, destruída, e o cortiço da Estela: 
Vou explicar como a coisa funcionava no cortiço da Estela. O lugar ficava a algumas quadras de onde eu morava. Várias vezes a polícia ia lá pra prender as prostitutas e os donos delas. [...].

O prédio tinha cinco andares e nada de elevador. Estela morava no quarto. Olhei em volta e percebi que o quartinho se resumia a um espaço muito pequeno, o banheiro ficava no corredor, porque era coletivo, assim como a cozinha, o que me deu certa alegria, pois parecia com o cortiço da Lapa. (TENÓRIO, 2013, p.55)

Este é o lugar onde João vai morar, quando sua casa é destruída e depois do suicídio do pai. A criança se vê sozinha nessa cidade triste e estranha. Subtrações ecoam por todo o romance dando a entender que nunca serão supridas. Beatriz Sarlo (2004) discute a pobreza e a subtração inscritas nos corpos que vagam por nossas cidades, corpos, geralmente, de crianças desnutridas de comida e amparo, sem ninguém para interceder por elas. Elas transitam nas margens, onde não ofendem ninguém com presença, porém, quando chegam ao centro, aos olhos dos que lá caminham, causam sempre um mal estar:

Há dezenas de milhares de crianças que não comem todos os dias, barrigudas e franzinas, raquíticas e vulneráveis. Há dezenas de milhares de adolescentes que nunca saem das quadras dos bairros afastados em que vivem, por medo, por distância cultural, por falta de recursos. Milhares de outros deixam seus bairros para sempre; são os habitantes da noite, dos túneis, dos becos, dos umbrais das lojas e dos edifícios. Esses corpos marcados pela miséria talvez até venham a receber um alimento amanhã, mas ele jamais compensará o que deixaram de receber hoje. Seus corpos estão sendo maltratados, ofendidos, desprezados, humilhados. (SARLO, 2004, p. 14)

Esse mal estar paira o tempo todo na narrativa, a solidão, o esconder-se dos outros por medo ou falta de entendimento. Há uma necessidade sempre presente de rompimento com a ordem imposta. É um médico amigo da família, a personagem para quem o menino pode relatar tudo o que lhe acontecera até ali, desde que havia chegado em Porto Alegre. Até aqui, a cidade é inóspita. Só tristeza, feiura e dor. Essa é a realidade do protagonista, ele está fora do sistema, é marginal. E assim são a maior parte das personagens de $\mathbf{O}$ beijo na parede (2013), com algumas exceções que se configuram em salvadores potenciais do ponto de vista do protagonista, são na verdade tão incapazes quanto o próprio garoto para exercer alguma mudança na estrutura social da cidade que é discutida no romance.

As diversas faces de uma cidade através dos tempos são estabelecidas por toda a sorte de personagens e narradores, de diversas idades, gêneros, posição social, desde diferentes lugares de fala. Porto Alegre se estabelece e se desenvolve nessas 12 narrativas. As relações com o espaço são múltiplas, portanto, as paisagens se constituem plurais. Temos o espanto da formação da metrópole, sua ligação fundacional urbana mais aproximada com a Belle Époque, os caminhos hídricos de seu crescimento, o desejo de seus habitantes e de forasteiros em habitá-la completamente, suas geografias noturnas e proibidas, o desejo de deixa-la para trás, o retorno, as construções mais impressionistas, mais pessoais, a exposição de suas cisões, de suas falhas estruturais, altos e baixos vão compondo a ideia desta cidade. A implicação desses modos de observação é a de que a experiência de urbanidade só produz imagens da cidade porque é por meio delas que se dá a tentativa da sua compreensão. Os sentidos dessas imagens são a própria construção da cidade como discurso. Se a cidade é como nós a vemos, a literatura se torna a narrativa do próprio desejo de ser na cidade e desse modo pode expor toda sua multiplicidade.

O pensamento-paisagem (Collot, 2011) se constitui também pela arte, pela literatura, neste caso, um modo de interpretação do espaço que habitamos. Os narradores, narradoras e personagens, em certo momento, são como o "Caminhante sobre o mar de névoa", pintura de Caspar David Friedrich, observando a imensidão da paisagem, sem se dar conta de que também são observados. Logo, o pensamento-paisagem proposto é costurado pelo leitor. No caso deste artigo, o que se estabelece é um amplo panorama da constituição narrativa de Porto Alegre. Seus itens da paisagem e seus realemas propõem - desde a flânerie de Neco e Chiquita, em Estrichnyna até a errância “inapropriada" de João - 
uma cidade que se codificou, se particularizou, e que, ao mesmo tempo, compartilha o ônus e o bônus da sua formação. Não se quer aqui orientar uma leitura evolutiva, pautada no desenvolvimento, nem mesmo criar dicotomias entre o passado e o presente. Os sentidos se alteram conforme o surgimento e a interpretação de certos itens da paisagem e realemas. Desse modo, ficamos sedentos pela emergência de novas histórias, novas personagens, vindas de lugares refeitos, repensados ou talvez nunca antes literários. A experiência de urbanidade a nós é fundamental para o que se determina como paisagem, e a exploração dos horizontes também é ponto crucial para a transformação do olhar que a elucida. Essa compreensão sintética das relações que unem os elementos constituintes da paisagem, e a construção de um significante por ela mesma, é um dos aspectos da estrutura do horizonte, a qual a fenomenologia utiliza para o entendimento da experiência do sensível, e que Collot, por sua vez, engloba na sua definição de pensée-paysage: "uma coisa não é jamais percebida senão na sua relação com as outras no interior de um campo, de um horizonte externo" (Collot, 2011:25, tradução nossa $)^{5}$. Assim, do mesmo modo que deve se levar em conta seu horizonte interno, sua face oculta, a percepção será sempre uma perspectiva subjetiva, um ato de pensamento, em que se pode criar uma ligação com a realidade referencial e um ponto de vista particular sobre o mundo. O invisível é o horizonte, a potência a qual o sujeito ainda não atribuiu sentido. A estrutura do horizonte permite compreender os elementos narrativos que unem o visível e o invisível, o limite e o desejo/expectativa, o imaginário e o referencial/real, ela elucida/ilumina a relação fundamental do ser no mundo, porque o horizonte faz parte da estrutura da experiência, revelado primeiramente através da percepção. Tanto a percepção quando a experiência são itens do campo da subjetividade, por isso nossa atenção devida à importância da construção das personagens e dos narradores na análise. Afinal, são eles que aqui nos convidam a imaginar cidades. Esses são nossos horizontes.

\section{Referências}

AZURENHA, Paulino; LOBO, Souza; TOTTA, Mário. Estrychnina. Porto Alegre: Artes e Ofícios, [1897], 1998.

COLLOT, Michel. Le pensée-paysage. Paris: Actes Sud, 2011.

COLLOT, Michel. Pour une géographie littéraire. Paris : Éditions Corti, 2014.

FAILLACE, Tania Jamardo. Mario/Vera. Brasil 1962-1964. Rio de Janeiro: Marco Zero, 1983.

FRANCO, Sérgio da Costa. Porto Alegre: guia histórico. Porto Alegre: EdiUFRGS, 1992.

GALERA, Daniel. Mãos de cavalo. Porto Alegre: Companhia das Letras, 2006.

HARVEY, David. A revolução urbana. Belo Horizonte: UFMG, 1999

HENRIQUES, Maria Lúcia. O Perdão, de Andradina de Oliveira : romance urbano na Belle Époque rio-grandense. Dissertação de mestrado. Porto Alegre: UFRGS, 2010. Disponível em http:// hdl.handle.net/10183/24040

JACOBS, Jane. Morte e vida nas grandes cidades. São Paulo: Martins Fontes, 2001.

MACHADO, Dyonélio. Os ratos. Rio de Janeiro: Civilização Brasileira, 1935.

MARRONI, Belmonte. E as águas invadiram a metrópole. Porto Alegre: Tip. Centro, [1942?].

MARTINS, Cyro. Estrada nova. Porto Alegre: Movimento, 1954.

MASSEY, Doreen B. Pelo espaço: uma nova política da espacialidade. Rio de Janeiro: Bertrand Brasil, 2008.

5 No original une chose n'est jamais perçue que dans son rapport à d'autres a l'intérieur d'un champ, d'un horizon externe. 
MONTEIRO, Charles. Porto Alegre e suas escritas: história e memórias da cidade. Porto Alegre: EDIPUCRS, 2006.

MOSCOVICH, Cíntia. Duas iguais. Porto Alegre: LP\&M, 1998.

NOLL, João Gilberto. Rastros do verão. Porto Alegre: L\&PM, 1986.

OLIVEIRA, Andradina de. O perdão. Porto Alegre: Livraria Americana, 1910.

PESAVENTO, Sandra Jatahy. O imaginário da cidade: visões literárias do urbano - Paris, Rio de Janeiro e Porto Alegre. Porto Alegre: Ed. Universidade/UFRGS, 2002.

POLESSO, Natalia B. Literatura e cidade: cartografias metafóricas e memória insolúvel de Porto Alegre (1897-2013). Tese de doutorado, PUCRS, 2017.

SARLO, Beatriz. Tempo presente: notas sobre a mudança de uma cultura. Rio de Janeiro: José Olympio, 2005.

SCLIAR, Moacyr. Os voluntários. Rio de Janeiro: Expressão e Cultura, 1979.

SCOTT, Paulo. Habitante irreal. Rio de Janeiro: Alfaguara, 2011.

TENÓRIO, Jefferson. O beijo na parede. Porto Alegre: Sulina, 2013.

VERISSIMO, Érico. Caminhos cruzados. Porto Alegre: Globo, 1935.

WESTPHAL, Bertrand. La géocritique: réel, fiction, espace. Paris: Les Éditions de Minuit, 2007. 
